\title{
Qaulan: Islamic-Based Learning Communication Model to Improve Students' Character
}

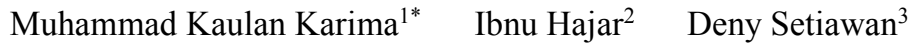 \\ 1.PhD Student of Basic Education, Universitas Negeri Medan, Medan, Indonesia \\ 2.Faculty of Education, Universitas Negeri Medan, Medan, Indonesia \\ 3.Faculty of Social Science, Universitas Negeri Medan, Indonesia
}

\begin{abstract}
This study aims at developing and examining the validity, practicality, effectiveness, activity, and students' responses to the implementation of Qaulan-based learning communication model in improving student's integrity character. This study approaches a development research design. The Model development refers to the Borg and Gall with development research procedures, namely: initial investigation, preliminary model development, expert validation and revision of revised product trials, and implement. The techniques for collecting the data are model validation sheets, expert and practitioner assessment sheets about the feasibility and effectiveness of the model, and student character observation sheets. This research come up with a Qaulan-based learning communication model with its valididy criteria for both the content and the construct, is practical, effective and also capable in improving student character.
\end{abstract}

Keywords: Qaulan, Learning Communication Model, Islamic Value, Character

DOI: $10.7176 / \mathrm{JEP} / 12-8-04$

Publication date:March $31^{\text {st }} 2021$

\section{Introduction}

Human resources are considered as valuable assets. Their quality will accelerate the development and civilization. The qualityis determined by how education is run in a country. According to Marzuki (2017), the quality of human resources determines the realization of the quality of a nation and state. This shows the importance of a decent education in determining the potential of the nation in the future, both from the social, economic and technological aspects (United Nations, 1997).

otherwise, in Indonesia, the main problem experienced is the downgrading of the human's character. This indicates that both religious and moral education taught in schools do not affect and change Indonesian's behavior.

The character of the post-reform is considered to be apprehensive, where the morality of the younger people is worse (Setiawan, 2013; Warsono, 2010). Pratiwi and Pritanova's research (2017) also found a decline in character currently that there is a tendency for children and adolescents to become accustomed to insulting others, to be jealous that force them into a depression and to be carried away by negative comments, and to be accustomed to speaking impolite. This is also confirmed by Festus (2012) that there are still students who display disrespectful attitudes, scorn and even underestimate educators (Festus, 2012). For that, there must be a character improvement effort to overcome the problem, one of which is by developing a learning communication model

\subsection{Statement of the Problem}

Learning communication should be delivered properly so that it can help calm one's mood, including lecturers and students. As research by Festus (2012) found that people who are in a good mood tend to have positive thoughts and vice versa and they tend to think negatively when their emotions are unstable. Effective communication for lecturers based on Islamic values is needed for students (Shahril, 2004). In an effort to improve the character of students who have greatly decreased.

For this reason, selective efforts are needed in choosing a learning communication model that is able to create a conducive atmosphere, which in turn helps students develop their potential (Johnson \& Roellke 1999; Hunt, Simons \& Cooper, 2002).

Until now, there have been no study or specific theories discussing the learning communication model, there only discussing communication theory in general, especially in learning communication based on Islamic values. Qaulan as a form and principle of communication in Islamic teachings written in the al-Qur'an. This qaulan can also be said as basic principles of communication.

\subsection{Significance of the Study}

In actual fact, there is no theory about the learning communication model at the moment. As well as learning communication based on Islamic values. So that the research on the development of this learning communication model is based on the circular communication model from Osgood and Schramm, which is further developed based on Qaulan, so that it can improve student character that is valid, practical, and effective 


\subsection{Research Questions}

The purpose of this study is how to develop a qaulan-based learning communication model to improve student character that is valid, practical and effective?

\section{Literature Review}

Character is the key element in education, it therefore must be included in the college curriculum (Heywood, 2013). Ibn Khaldun (1993) also added that education is inseparable from moral development, education must be able to make students discover and establish these universal values in life (Knellr, 1972).

In the 21 st century in particular, one must have multiple skills, it is in accordance to Morocco, et.al. (2008) skills and focus of expertise needed in this era of digitalization include some creativity and innovation, critical thinking, communication skills, and collaboration.

Regarding to communication skills, Kumar (2014) states that in the current competitive world conditions, communication skills are a coveted skill and must be possessed by educated people. Ekron in his dissertation stated that effective and clear communication is essential in the process of making meaning (Ekron, 2015).

Also, communication skills are not only required for students but also must be possesed by educators to encourage their students to have the skills. In this context, their skills are considered as an effort to express oneself in a sustainable, integral and dynamic manner considering the various differences among students, including character, culture, growth and development processes they go through (DeVito, 1997; Urea, 2013), but at the same time it is aimed at making students to be more adaptive and competitive in this era.

As the main role during the learning process, educators have a big influence in creating a conducive atmosphere and developing the students' poetentials. indeed, the communication shown by educators should be open, empathetic and supports the students' development (DeVito, 1997). Kevin John Loy's dissertation (2006) found that communication contributes to improve student achievement, and is essential that it one of the principles and standards in school listed. Thus, communication skills or abilities are important for educators.

On previous study, it was found that learning communication at the higher education still become a continuous problem, including students who were embarrassed, reluctant, indifferent, telling stories with friends when lecturers were teaching, playing gadgets, completing other assignments, even do not focus in the lecture process (Marentek, Sondakh \& Kawengian, 2018; Mutawakkil \& Nuraedah, 2019). Meanwhile,a study by Munawaroh, Kusmayadi, and Usodo (2015) stated that learning process and communication are always resulting in the cognitive and the humanities asprcts are seem to be neglected, in other words, academic achievement is just the way more prioritized than human development . also in further analysis, it is often found that there are misconnection between the lecturer and students' communication so the learning process remains unconducive (Francisca \& Clara, 2016). This has been confirmed by some other studies that learning communication by educators is less conducive, resulting in saturation, ineffective of students in learning (Marentek, Sondakh, \& Kawengian, 2018; Mutawakkil \& Nuraedah, 2019; Dannels, Anson, Bullard, \& Peretti , 2003). According to Dannels, et.al. (2003), four learning issues emerged in student reflection logs: integrating multidisciplinary information, managing varied audiences and feedback, aligning content and communication tasks, and addressing interpersonal team issues.

The challenges experienced by lecturers, communication in particular, are complex problems that must be fixed through an effective communication model based on the inculcation of the values of goodness and truth so as to improve the character of students (Fattah, 2009; Jasmi \& Tamuri, 2012).

\section{Research Methodology \\ 3.1 Type of Study}

This research is development research. In this study, a qaulan-based learning communication model is developed, learning tools, and the instruments needed. The model development procedure refers to the Borg and Gall model, namely: (1) initial investigation, (2) initial model development, (3) expert validation and revision, (4) revised product trial, and (5) apply (Gall, Gall, \& Borg, 2003). The products of this study were evaluated based on aspects of product quality according to Nieveen (1999). namely: validity, practicality, and effectiveness.

\subsection{Instruments of Data Collection}

The three instruments to measure the validity, practicality and effectiveness of the model are (1) the model validation sheet; (2) expert and practitioner assessment sheets regarding the feasibility and effectiveness of the model, (3) student character observation sheets. The validation sheets used are: (a) the book validation sheet for the Qaulan-based learning communication model; (b) RPS validation sheet, (c) validation sheet for student character observation instruments.

Examining the validity of the model validation sheet refres to its content, construct, language and design while the assessment of the validity of the Semester Learning Plan based on these aspects, (1) indicators, (2) content presented, (3) language (4) time, (5) learning methods / activities, (6) closing. And assessment of the 
validity of the Student Character observation sheet are based on these points (1) material, (2) construction, (3) use of language.

The criteria for being a developed and valid learning model are marked by five rating scales (Very Valid = 5 , Valid $=4$, Enough $=3$, Less Valid $=2$, Invalid $=1$. The trial was conducted through the small group trial stage (six people ), and field trials (15-30 people) (Dick \& Carey, 2006).

Validity test with product moment correlation-formula, Releability test with alpha coefficient-formula. This research was analyzed using descriptive statistical analysis. The validity of learning models and tools is based on the assessment of four experts in the field of model development and two learning practitioners. The practicality of the model is seen from the consistency of intended perception (IP), which is obtained from the results of expert and practitioner assessment and intended operational (IO), which is obtained from the results of observers' assessment in the implementation of classroom learning. The effectiveness of the model is seen from the consistency of the intended experimental (IE) results, which is obtained from the results of expert and practitioner assessment and intended attained (IA), which is obtained from the achievement of indicators / aspects of effectiveness determined based on field trial data analysis.

\section{Findings}

\subsection{Research Question 1}

What is the Initial Investigation task to determine the conditions of learning and the needs of students and lecturers in learning?

This activity is carried out by distributing questionnaires that have been tested for validity and reliability to 35 students and 1 lecturer to determine the conditions of learning so far, as well as the need for learning communication models that can improve student character. The student indicators are divided into four, namely Honesty, Discipline, Responsibility, and Consistency. The results obtained by students' answers related to the learning process, that today's learning has not been able to improve character with an average value of 2.40. Meanwhile, the value of student needs regarding the learning communication model is categorized as high with an average of 4.58. While the questionnaire given to lecturers about the learning process obtained an average value of 2.26, this shows that the lecturer confirmed that the four competencies had not been touched in learning so far. Likewise, the needs analysis with an average value of 4.58 is categorized as high. This information can be seen in table 1.

Table 1. Results of Students and Lecturers' Assessments on Character Learning, and the Need for a Learning Communication Model

\begin{tabular}{ccccccc}
\hline \multirow{2}{*}{ Result } & \multirow{2}{*}{ Indicator } & \multicolumn{3}{c}{ INDICATOR (EACH CHARACTER) } & \multirow{2}{*}{ Average } \\
& & Honesty & Discipline & Responsibility & Consistency & 2,40 \\
Student & Learning & 2,27 & 2,69 & 2,28 & 2,38 & 2,40 \\
& Need & 4,57 & 4,66 & 4,51 & 4,59 & 4,58 \\
\multirow{2}{*}{ Lecturer } & Learning & 2,11 & 2,55 & 2,25 & 2,12 & 2,26 \\
& Need & 4,66 & 4,60 & 4,45 & 4,56 & 4,58 \\
\hline
\end{tabular}

\subsection{Research Question 2}

What is the initial process of developing a Qaulan-based learning communication model?

After getting initial information about today's learning as well as an analysis of the needs for a learning communication model that can improve student character, an initial model of learning communication based on Qaulan was designed. These activities include: (1) establishing the theories that underlie the content and construction of a Qaulan-based learning communication model, (2) designing model components based on supporting theories of the model (syntax, social systems, reaction principles, support systems, impact instructional and accompaniment impact), (3) selecting the model book format.

The grand theory adoption in the learning communication model developed is perennialism philosophy, humanistic learning theory, Osgood and Schramm's circular communication model, and the content of the meaning of Qaulan in the Koran as a principle of Islamic communication. Produce a successful designed learning communication model scheme which has stages. 

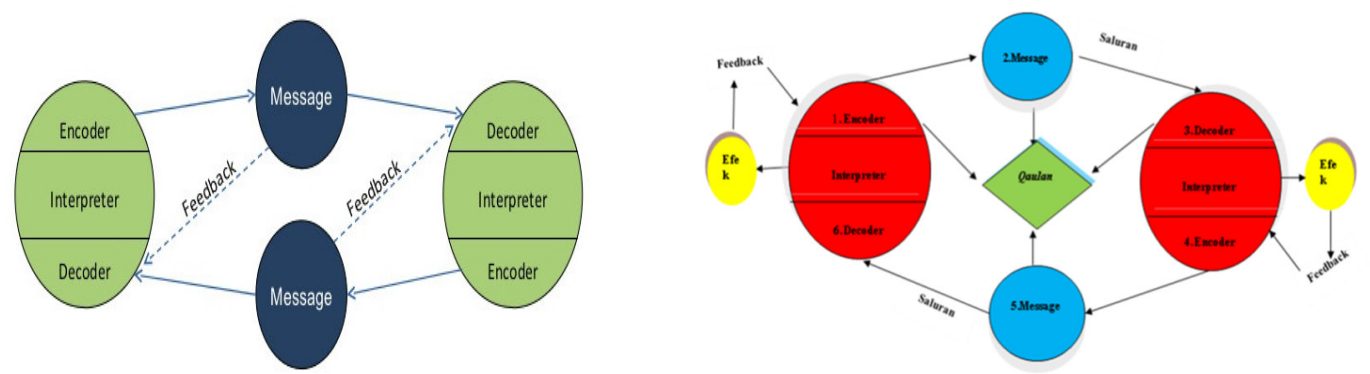

Figure. 1. Osgood and Schramm's Model and the Results of the Development of Qaulan-Based Learning Communications

Table2. The steps of the Qaulan-based learning communication model

\begin{tabular}{ll}
\multicolumn{1}{c}{ Steps } & \multicolumn{1}{c}{ Description } \\
\hline Ideation & communicator's ideas / ideas must be accompanied by a sense of sincerity \\
\hline Encoding & The message delivered that contains goodness and truth values \\
\hline Transmission & Delivering clear statement with a proper intonation \\
\hline Receiving & Communication should be run wisely \\
\hline Decoding & Communication in delivering message interpretation \\
\hline Action & Feedback that is delivered should be truthful and proper-based \\
\hline
\end{tabular}

\subsection{Research Question 3}

How do expert validation and revision of instruments and outputs developed?

The result of expert validation on the validation instrument is the book validation sheet for the Qaulan-based learning communication model with average 0.82, the validation sheet for the Semester Class Plan with average 0.86 , and the validation sheet.

The student character observation instrument with average 0.83 is categorized as proper and valid, after revising some aspects.

Table 3. Expert Validation Recapitulation on Model books

\begin{tabular}{|c|c|c|c|c|}
\hline No & Validation & Validation Description & Average & Explanation \\
\hline \multirow{4}{*}{1.} & \multirow{4}{*}{ Model Book } & Matery & 0,82 & Valid \\
\hline & & Construction & 0,82 & Valid \\
\hline & & Langauge & 0,83 & Valid \\
\hline & & Average & $\mathbf{0 , 8 2}$ & Valid \\
\hline \multirow{7}{*}{2.} & \multirow{7}{*}{ Semester Learning Plan } & Indicator & 0,81 & Valid \\
\hline & & matery & 0,89 & Valid \\
\hline & & Language & 0,88 & Valid \\
\hline & & Time Alocation & 0,91 & Valid \\
\hline & & Method & 0,81 & Valid \\
\hline & & Closing & 0,85 & Valid \\
\hline & & Character & $\mathbf{0 , 8 6}$ & Valid \\
\hline \multirow{4}{*}{3.} & \multirow{4}{*}{ Character Observation Sheet } & Matery & 0,85 & Valid \\
\hline & & Construction & 0,84 & Valid \\
\hline & & Language Use & 0,80 & Valid \\
\hline & & Average & $\mathbf{0 , 8 3}$ & Valid \\
\hline
\end{tabular}

The qaulan-based learning communication model and the output compiled by expert assessments presented in table 4.7, validation of observations of student integrity character obtaining 0.83. Referring to Azwar (2014) that if the range of number $\mathrm{V}$ obtained is $\geq 0.667$ it can be interpreted as a high coefficient, so that it can be categorized that the validity category is in the "valid" category. Before valid tested, it must be revised and improved as suggested by experts. Table 4 shows the summary notes. 
Table 4. Expert notes Recapitulation for Revision

\begin{tabular}{|c|c|c|}
\hline Category & Pre-Revision & Post-Revisi \\
\hline \multirow{4}{*}{ Model Book } & Language use needs to be improved & $\begin{array}{l}\text { Improvements in writing structure have } \\
\text { been completely done. }\end{array}$ \\
\hline & Note-taking book need to be fixed & $\begin{array}{l}\text { Some of the writing errors have been } \\
\text { corrected }\end{array}$ \\
\hline & $\begin{array}{l}\text { Add a theoretical study related to } \\
\text { thecommunication model in Chapter II }\end{array}$ & $\begin{array}{l}\text { The theoretical study has been developed } \\
\text { in accordance with the developed } \\
\text { communication model }\end{array}$ \\
\hline & Add Grandtheory & Grandtheory is added \\
\hline \multirow[t]{2}{*}{ Learning Tools } & $\begin{array}{l}\text { Selection of learning strategies need to } \\
\text { emphasize the output of study, and aspects } \\
\text { of the study process; }\end{array}$ & $\begin{array}{l}\text { The strategy has been adapted to the } \\
\text { output of student studies and the study } \\
\text { process aspects. Percentage of } \\
\text { assessments at the participation stage has } \\
\text { been } 25 \%\end{array}$ \\
\hline & $\begin{array}{l}\text { Percentage of marking at the Participation } \\
\text { stage in learning must be } 25 \% \text {. } \\
\text { Book writing needs to be improved }\end{array}$ & $\begin{array}{l}\text { Some of the writing errors have been } \\
\text { corrected }\end{array}$ \\
\hline
\end{tabular}

\subsection{Research Question 4}

How do experts and practitioners analyse the Qaulan-based learning communication model developed?

The practicality of Qaulan-based learning communication model is shown from the consistency of these two aspects, namely intented $\leftarrow \rightarrow$ perseived (IP) obtained from the measurement results, then the intended $\leftarrow \rightarrow$ operational (IO) obtained from the results in the implementation of classroom learning.

After the test done by experts and practitioner, the Qaulan-based learning communication model confirmed has IP and IQ degree, they achieve high category. This also proves that the Qaulan-based communication model does not need improvements.

Table 5. The result of the Qaulan-based learning practical communication model test

\begin{tabular}{|c|c|c|c|c|}
\hline No & Aspect & Description & Average & Category \\
\hline \multirow{4}{*}{1.} & \multirow{4}{*}{ intended $\leftrightarrow$ perseived (IP) } & Syntax & 4,22 & High \\
\hline & & Social system & 4,39 & High \\
\hline & & Principles of learning management & 4,40 & High \\
\hline & & Average & 4,34 & High \\
\hline \multirow{4}{*}{2.} & \multirow{4}{*}{ intended $\leftrightarrow$ operational $(\mathrm{IO})$} & Syntax & 4,26 & High \\
\hline & & Social system & 4,44 & High \\
\hline & & Principles of learning management & 4,39 & High \\
\hline & & Average & 4,36 & High \\
\hline
\end{tabular}

Based on the results obtained from the assessment of experts and practitioners (intended perseived) with the observation of the implementation of the Qaulan-based learning communication model in the field by observers (intended operational), it is said that there is consistency between the results of the assessment, namely both providing high assessment results, so the model meets the criteria of practicality.

\subsection{Research Question 5}

How does the effectiveness of the developed Qaulan-based learning communication model examined?

Knowing the effectiveness of the Qaulan-based learning communication model is shown by seen the consistency of the results of two measures, namely intended experimental (IE) obtained from the results of expert and practitioner assessments) and intended attained (IA) measures obtained from the achievement of indicators / aspects of effectiveness determined based on field trial data analysis .

Determining IE (intended experimental) to accepted is based on theory and experience of experts and practitioners have, whether the Qaulan-based learning communication model can be applied effectively in the implementation of learning in the classroom by four aspects: (1) student character, (2) student and lecturer activities , (3) the ability of the lecturer to manage learning, (4) components and the learning process.

Accepting IA (intended attained) is determined based on empirical data on the application of a Qaulan-based educational communication model in the implementation of classroom learning by four aspects: (1) Data on Student Integrity Character Achievement (2) achievement of the best time percentage of student and lecturer activities, (3) the achievement of the value of the ability of the lecturer to manage learning, (4) the percentage of many students who responded positively to the components and learning activities. where the model trials were carried out in the small group trial class and the Field Group Trial class. The results of the recapitulation of expert 
and practitioner assessments as well as empirical data on the application of the Qaulan-based learning communication model in learning can be seen in table 6 .

Table 6. The result of the effectiveness of the Qaulan-based learning communication model test

\begin{tabular}{|c|c|c|c|c|}
\hline No & Subject & Aspect & Mark & Category \\
\hline \multirow[t]{5}{*}{1} & Expert & Student's Integrity Character & 4,22 & High \\
\hline & & Student and Lecturer Activities & 4,39 & High \\
\hline & & Learning Management skill & 4,40 & High \\
\hline & & Components and Learning Process & 4,47 & High \\
\hline & & Average & 4,34 & High \\
\hline \multicolumn{5}{|c|}{ Small Group Trial } \\
\hline \multirow{6}{*}{2} & Lecturer & & 4,46 & High \\
\hline & Student & Student's Integriry Character & 83,50 & Effective \\
\hline & Lecturer and & Students and Lecturer's activity & All (fulfilled) & Ideal \\
\hline & Lecturer & Learning management skill & 3,54 & Enough \\
\hline & Student & $\begin{array}{l}\text { Students' response to learning components and } \\
\text { process }\end{array}$ & 85,83 & Efective \\
\hline & Lecturer & Learning Tools & 84,12 & Efective \\
\hline \multirow{7}{*}{3} & & $\begin{array}{l}\text { Field Group Trial } \\
\end{array}$ & & \\
\hline & Lecturer & Student's Integrity Character & 4,46 & High \\
\hline & Student & & 86,43 & Efektif \\
\hline & $\begin{array}{c}\text { Lecturer and } \\
\text { Student }\end{array}$ & Students and Lecturer's activity & All (fulfilled) & Ideal \\
\hline & Lecturer & Learning management skill & 3,55 & Enough \\
\hline & Student & $\begin{array}{l}\text { Students' response to learning components and } \\
\text { process }\end{array}$ & 90,04 & Efective \\
\hline & Lecturer & Learning Tools & 85,97 & Efective \\
\hline
\end{tabular}

The results obtained from the four indicators in the small group show that the students' integrity ability, the achievement of the ideal percentage of student and lecturer activities, the achievement of the ability of lecturers to manage learning is at least quite good, and at least $80 \%$ of the many subjects studied (for each trial) gave a response. which is positive for components and learning activities, fulfilled and considered as effective.

While the results from the four indicators in the field group show that the student's integrity ability, the achievement of the percentage of the best time for the defined student and lecturer activities, the achievement of the ability of lecturers to manage learning is at least quite good, and at least $80 \%$ of the many subjects studied (for each trial) give a positive response to the components and learning activities, fulfilled and considered as effective. Not only that, it can be seen from the implementation of the learning tools that the average lecturer response is in the good category. Then all development processes and products resulting from the development research carried out are accepted as effective and usable.

\section{Discussion}

The modern era has positive impact, where effectiveness and efficiency are priorities. However, on the other hand, it also showsa lot of inequality, chaos, confusion, and various problems. For this reason, education must be able to improve human resource skills without declining good values that come from religion or culture (Assegaf, 2011).

Education and learning must be able to help students develop their potential. Educators may help raise the hidden potential from every students so that meaningful learning is a necessity that must be realized, and students can experience the true values.

It is confirmed by Sardiman's (2005) opinion that teaching is a process with the function of guiding students in living life, namely guiding and maximizing self-potential in accordance with the development process that students must experience. Their tasks include the need to survive as individuals and as social beings also as creatures of the God.

As a humanistic religion, Islam is established on human-value foundation. For that, Islamic teachings are a source of value in education that must be applied. In fact, it is not as expected, where education and the learning process in educational institutions is seen as less democratic. The lack of a place for students to develop their imagination and creativity with their point of view. while, the creativity and critical thinking are valuable assets for student to overcome challenges and become more competitive (Arbayah, 2013).

Learning must emphasize free will, personal growth, joy, the ability toexperience happiness, and success in raising human potential. Humanistic goals are to help humans express themselves creatively and hone their full potential. 
The principle of freedom in humanistic education is different from the concept of freedom in religious teachings, where education is directed to make an approach to God through human experience. Although there are similarities with secular education, religious education has added value. This added value is an advantage, namely relying on spiritual values in order to create real human beings such as the direction of humanistic education in Islam.

Some fforts to change the paradigm that has long been used in learning in educational institutions, where time is wasted just listening to teacher lectures explaining the material, to a learning paradigm that is seen as more appropriate to the dignity of students as humans in learning by implementing communication that respects and respects participants students. These efforts have not always remained satisfactory results. If educators apply the same teaching approach (based on previous teaching experience) in a learning system that has undergone a change, then it is possible that the learning objectives or character expected by students are not achieved. This requires effective communication skills in learning (Hendra, 2017; Ekron, 2015; Roscoe, 2009; Loy, 2006; Olive, 2004; Johnson, and Roellke, 1999; Roux, 1990 ;; Rubin \& Feezel, 1986). Educators must be able to build communication and individual relationships with individuals and individuals with groups so that they are able to motivate and inspire students to develop their potential so that they have superior character.

However, effective communication found in previous research has not analyzed the values contained in communication. In fact, the learning communication must contain goodness and truth values. Religion is the main source of value, including in terms of communication. The Koran states that communication is one of human nature. The Koran also provides some key words (keyconcept) that guide people to communicate not only properly and correctly, but also to get the pleasure of Allah.

Why "Qaulan", because the word qaulan is an expression closed in the Koran. Where qaulan ,in the Koran, is associated with a good and praised, that's what intelligent beings must do (Ilahi, 2010). Thus, the communication context here lies in the language of "understanding" in communicating. This understanding is of course the language of communication in the corridors of truth.

Also, according to Asyafah (2014), although religion is considered fundamental in instilling and enhancing the character of the nation, teaching and learning based on religion is still more limited in Indonesian education settings. So that the development of a Qaulan-based learning communication model as a principle or value of communication in Islam is needed in improving student character. For this reason, it is also necessary to develop a learning communication model that can be used as a guide for lecturers in implementing learning.

The learning communication model developed is based on the word Qaulan which contains the values of goodness and truth because it comes from God's revelation as the main source in developing the character of students. In this study, the learning communication model is a learning communication design or pattern that is used as a guide in planning and realizing an effective learning communication process in the classroom, so that the specified learning objectives can be achieved.

The qaulan-based learning communication model has been validated and tested for its validity, practicality, and effectiveness in improving student character.

This shows that this learning communication model has succeeded in making education capable of developing human dignity or treating humans as humanizing humans so that they become real humans (Mastuhu, 2003). because the communication carried out in learning has the principles of goodness and truth.

\section{Conclusion}

The conclusions of this study are:

- The development of a Qaulan-based communication model is considerably valid, practical, and effective so that it has clear, comprehensive, and strategic steps to facilitate lecturers and students in interpreting learning activities, and learning communication that can be used.

- Learning tools based on the Qaulan communication model developed are considered valid by experts, considered practical by users and proven effective. This learning tool can be used as a guide to improve the quality of learning which can provide opportunities for lecturers and students to practice communication skills, solve problems, build and actualize their abilities by giving opportunities to lecturers and students as subjectlts or objects of the learning process itself.

- The developed Qaulan-based communication model book is considered valid by experts, is considered practical and proven effective by users, and is able to improve student character.

\section{References}

Assegaf, A. R. (2011). Philosophy of Islamic Education. Jakarta: RajaGrafindo Persada. Arbayah. 2013. Humanistic Learning Model. Jurnal Dinamika Ilmu, 13(2), 204-220.

DeVito, J. A. (1997). Communication between people: basic lectures. Jakarta: Professional Books.

Dannels, D. P., Anson, C. M., Bullard, L., \& Peretti, S. (2003). Challenges in learning communication skills in chemical engineering. Communication education, 52(1), 50-56. https://doi.org/10.1080/03634520302454 
Ekron, Christélle. (2015). Learning to teach: Communication skills in teacher education. (Dissertation). Department of Curriculum Studies Faculty of Education Stellenbosch University.

Fattah, Abdul Abu Ghuddah. (2009). Rasulullah best educator: 40 teaching techniques of rasulullah.. Translator. Hj Shuhadak Mahmud. Negeri Sembilan: Al-Azhar Media.

Festus, A.B. (2012). The relationship between emotional intelligence and academic achievement of senior secondary school students in the Federal Capital Territory, Abuja. Journal of Education and Practice, 3(10), 13-19. https://www.semanticscholar.org/paper/The-Relationship-between-Emotional-Intelligence-andFestus/95fc67d764e57b6f29391da5c2ffad82fdcd30f5

Francisca, Leonie dan Clara R.P. Ajisuksmo. (2015). The relationship between moral knowing, moral feeling, and moral behavior in the four basic competencies of teachers. Jurnal Kependidikan, 45(2), 211-221.

Gall, Meredith D, Joyce P.Gall, Walter R.Bor. (2003). Educational research: an Introduction. New York: Logman Inc.

Heywood, David. (2013). Educating Ministers of Character: Building Character into the Learning Process in Ministerial Formation. Journal of Adult Theological Education, 10(1), 4-24. https://doi.org/10.1179/1740714113Z.0000000001

Hunt, S., Simonds, \& Cooper. (2002). Communication and teacher education: Exploring a communication course for all teachers. Journal Communication Education, 51 (1), 81-94.

Jasmi, Kamarul Azmi, \& Ab. Halim Tamuri. (2012). Islamic education teaching and learning methods. Skudai: Universiti Teknologi Malaysia.

Johnson, S.D. and Roellke, C.F.. (1999). Secondary teachers' and undergraduate faculty members' perception of teaching-effectiveness criteria: A national survey. Communication Education [Electronic], 48(2). 127-138. http://dx.doi.org/10.1080/03634529909379160

Khaldun, Ibnu. (1993). Muqaddimah. Beirut: Dar al-Kutub al-Ilmiyyah.

Knellr, George F. (1972). Introduction to the philosophy of education. New York: Jhon Wiley \& Sons, Inc.

Kumar, R. (2014). Business communication and etiquettes. New Delhi: NMIMS Global Access.

Loy, Kevin John. (2006). Effective teacher communication skills and teacher quality. (Dissertation) The Ohio State University.

Marentek, Yosua R., Mariam S., \& Debby K. (2018). Lecturer interpersonal communication patterns in improving learning achievement of sommunication science students. Jurnal Online Acta Diurna. 7 (2), 1-16.

Marzuki, (2017). Islamic Character Education. Jakarta: AMZA.

Mutawakkil \& Nuraedah. (2019). Lecturer communication style in student learning. communicatus: Journal of Communication Studies. 3(2), 135-153.

Morocco, C.C., et al. (2008). Supported literacy for adolescents: transforming teaching and content learning for the twenty-first century. San Faransisco: JosseyBass A Wiley Imprint.

Nieveen, Nienke. (1999). Prototyping to reach product quality. In Jan Van den Akker, R.M Branch, K. Gustafson, N. Nieveen, \& Tj. Plomp. Design approaches and tools in education And Training. Dordrecht, The Netherlands: Kluwer Academic Publisher.

Pratiwi, N., \& Pritanova, N. (2017). The influence of digital on chil and adolescent psychology. Jurnal Semantik, $6(1), 11-24$

Roscoe, C. (2009). Teaching and learning communication, language and literacy. Early Years an International Research Journal. Vol. 29, No. 3, October 2009, 293-298https://doi.org/10.1080/09575140903180701

Roux, J., Le. (1990). Communication in teaching and learning. South African Journal of Education, 10 (5/6), 426430.

Rubin, R. B., \& Feezel, J. D. (1986). Elements of teacher communication competence. Journal Communication Education, 35, 14-27.

Sardiman. (2005). Interaction and teaching and learning motivation. Jakarta: PT Raja Grafindo.)

Setiawan, Deny. (2013). The role of character education in developing moral intelligence. Jurnal Pendidikan Karakter, 3(1), 53-63.

Shahril, Charil Marzuki. (2004). Effective teaching practices: a study in several secondary schools in the federal territory and Selangor. Jurnal Pendidikan, (24), 29-40.

United Nations. (1997). Report On The World Social Situation 1997. New York: United Nation.

Urea, Roxana. (2013) The impact of teachers' communication styles on pupils' selfsafety throughout the learning process. Procedia - Social and Behavioral Sciences (93), 164-168.

Warsono. (2010).Character Education Model Through Citizenship Education. Proceedings of The 4th International Conference on Teacher Education. Conference UPI \& UPSI Bandung, Indonesia

Muhammad Kaulan Karima, M.Pd. (Magister of Education). He is a lecturer at the State Islamic University of North Sumatra Medan who is currently pursuing his doctoral education at the Medan State University in the Basic Education study program, currently serving as the head of academic and institutional affairs at Sekolah Tinggi 
Ilmu Tarbiyah Al Ittihadiyah Labuhanbatu Utara. ORCID: 0000-0003-1885-5122. Email address: kaulankarima@uinsu.ac.id

Prof. Dr. Ibnu Hajar, M.Pd. he is a professor and lecturer at the State University of Medan and as the Chancellor for the 2011-2015 period. Ever too, Chancellor at Asahan University. Currently. Chairman of the Education Service Intitution (L2Dikti), Regional of North Sumatra, Email address: ibnu@unimed.ac.id

Dr. Deny Setiawan, M.Si. He is a lecturer at the State University of Medan, and Assessors at the National Accreditation University (BAN-PT). Email address: denysetiawan1978@gmail.com 